Lord Alcester assures me that there was no doubt of the breakers, otherwise it might be thought that the deceptive appearance that misled Captain Aldrich, also misled the officers of the Pelorus.

It thus appears probable that, as in some other cases (of which the Graham Island in the Mediterranean is perhaps best known), the cinders and ashes which formed, and still form, the summit of the volcanic mound originally thrown up, are being by wave-action gradually swept away, and will continue to be so removed until the top of the bank is reduced below the limit of such action, or, as in the case of the Graham Shoal, the solid rock is laid bare.

If so, it is another case of the preparation of a suitable foundation for coral builders by a process directly the reverse of that of building up by marine organisms on mounds that have failed to reach the surface, suggested by Mr. John Murray to be the principal method.

It remains for those who have made submarine eruptions their study to say whether a mound raised in the sea is covered with loose matter in a sufficient percentage of cases to justify this mode of coral-foundation-making being given an important place amongst others.

In the latest known cases of islands so formed, viz. Steers and Calmeyer Islands, thrown up near Krakatao in 1883 , and Falcon Island, which appeared in 1885 in the Tonga Group, the surface structure was loose. The two former very shortly disappeared below the level of the sea. What is happening to the latter is not known, as it is seldom sighted; but from its volume and height (z9o feet) the process of reduction, even if no compact nucleus exists above water, must be slow.

The deceptive appearance of the masses of minute organisms which floated in the vicinity of the bank is no doubt an abundant source of false reports. These clouds of matter are commoner in inclosed and calmer waters, like the Red Sea, than in open oceans, where they are so much more liable to be dispersed by the waves before they can accumulate to any size. The assistance they afforded in this instance to the searchers is remarkable, and so far as I know unique, as they are generally found in deep water.

$$
\text { W. J. L. WHARTON. }
$$

\section{RECENT VISIT OF NATURALISTS TO THE GALAPAGOS.}

CAPTAIN J. M. DOW has placed at my disposal the subjoined short account of a visit recently paid to the Galapagos Group by the United States steamer Albatross, which will, I am sure, be of much interest to naturalists.

$$
\text { P. L. Sclater. }
$$

\section{U.S. Commission of Fish and Fisheries,} Steamer "Albatross," Acapulco, Mexico,

\section{Captain J. M. Dow, Panama.} April 24, I888.

MY DEAR SIR,-Thinking that you might like to know something of the results of our trip to the Galapagos, I take this opportunity of writing.

Leaving Panama on the morning of March 30, we made during that day six hauls of the trawl in depths from 7 to $5 \mathrm{I}$ fathoms. These gave us fine results, including many species with which you are doubtless familiar. The fishes included species of Upeneis, Arius, Polynemus, Aphronitia, Serranus, Selene, Prionotus, Hcmulon, Synodus, Tetrodon, Ophidium, Scicna, Micropogon, Lophius. We were delighted to see Thalasophryne and two allied species. The number of shells, Crustacea, \&c., was almost innumerable. The care of so much material kept us very busy. The next day we sounded off Cape Mala, and found the depth to be 1927 fathoms. No more dredging was done until we neared the Galapagos on, April 3, when we made a haul in 1379 fathoms, where the amount of material obtained was small, although it included some very good things. At the islands we made visits to eight of the principal ones, Most of our days were spent on shore, beginning early in the morning, and oftentimes bird-skinning and other work was prolonged far into the night. The islands presented a very inhospitable look along the shores, with the black lava cropping about everywhere; but in two of them (Chatham Island and Charles Island) the interior was extremely fertile and pleasant. Collecting was always difficult; but, with the co-operation of officers and men, we obtained a great quantity of material. We naturally looked to the birds first, on account of Darwir's previous work there. We have over 250 good bird-skins, besides several hundred specimens in alcohol, and a few skeletons. Of the fifty-seven species before reported from there, we obtained examples of fifty or more, and we have, in addition, several which are apparently new to science. We hope, with our material, to settle some of the curious problems of these islands.

We secured specimens of all the reptiles which have been before found there, and also hope that we have two or three new lizards. The tortoises excited great interest, and it would please you to see the many large ones which are now crawling about our decks. We expect now that we shall be able to raise them in the States.

Fishing was good at all of our anchorages, and we all had sport in catching fishes over the ship's side. We got between thirty and forty species in all, including a large brown "grouper," which is there caught and salted for the Ecuador market.

One night, while running from one island to another, we stopped and drifted for a while, and put the electric light over the side. Besides many small things, large sharks came around in great numbers. More than twenty were seen at once, and I know that the sight would have pleased you. We all regretted that you were not with us. Notwithstanding the necessity for rapid work, goodfellowship a?ways prevailed as usual. I hope that some time you may take a trip with me on the Albatross, and see how we do it.

Hoping that this will not prove too long an account for you,

I remain, Yours very sincerely,

\section{LESLiE A. LeE.}

\section{THE BRITISH ASSOCIATION.}

Section A-Mathematical and Physical Science.

A Simple Hypothesis for Electro-masnetic Induction of In. complete Circuits; with Consequent Equations of Electric Motion in Fixed Homogreneous or Heterogeneous Solid Matter, by Sir William Thomson.

(I) To avoid mathematical formulas till needed for calculation consider three cases of liquid ${ }^{1}$ motion which for brevity I call Primary, Secondary, Tertiary, defined as follows:- Half the velocity in the Secondary agrees numerically and directionally with the magnitude and axis of the molecular spin at the corresponding point of the Primary ; or (short, but complete, statement) the half velocity in the Secondary is the spin in the Primary, and (similarly) half the ielocity in the Tertiary is the spin in the Secondary.

(2) In the Secondary and Tertiary the motion is essentially without change of density, and in each of them we naturally, therefore, take an incompressible fluid as the substance. The motion in the Primary we arbitrarily restrict by taking its fluid also as incompressible.

(3) Helmholtz first solved the problem-Given the spin in any case of liguid motion, to find the motion. His solution consists in finding the potentials of three ideal distributions of gravitational matter having densities respectively equal to $1 / 4 \pi$ of the rectangular components of the given spin; and, regarding

"I use "liquid" for brevity to signify incompressible fluid. 